дитину так, щоб вона переймалася моральністю божественного і людського світу, і не протиставляла йому своє самолюбне я» [5, с. 25].

Отже, духовність вихователя, моральний вплив освіти, що грунтується, насамперед, на кращих зразках рідної культури, а також ідеях геніїв людства про добро і благо особистості, iї гідності та честі, свободу вибору, є основою духовно-морального виховання учнівської молоді, метою якого $є$ не миттєвий результат, а поступове досягнення ідеалів. Перспективою дослідження $\epsilon$ аналіз проблеми духовно-морального виховання особистості у практичній діяльності сучасних педагогів.

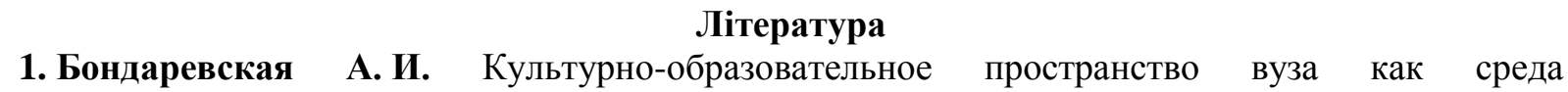
профессионально-личностного саморазвития студентов: автореф. дис. на соискание ученой степени канд. пед. наук : спец. 13.00.08 «Теория и методика профессионального образования» / А. И. Бондаревская. - Ростов н/Д : Ростовский гос. пед. ун-т, 2004. - 23 с. 2. Вахтеров В. П. Основы новой педагогики / Василий Порфирьевич Вахтеров. - М. : Т-во И. Д. Сытина, 1913. - 583 с. 3. Вернадский В. И. Философские мысли натуралиста / В. И. Вернадский. - М. : Наука, 1988. 522 с. 4. Гессен С.И. Основы педагогики. Введение в прикладную философию / Сергей Йосифович Гессен ; отв. ред. и сост. П. В. Алексеев. - М. : Школа-Пресс, 1995. - 448 с. 5. Каптерев П. Ф. Новая русская педагогия, ее главнейшие идеи, направления и деятели / Петр Федорович Каптерев. - [изд. 2-е, доп.]. - СПб. : Книжн. склад «Земля», 1914. - 211, [1] с. 6. Кондратьева Е. А. Культурно-образовательное пространство сельской школы как среда личностного развития школьника : дис. ... канд. пед. наук : 13.00.01 / Елена Анатольевна Кондратьева. - Ростов н/Д. : Ростовский гос. пед. ун-т., 2005. - 186 с. 7. Корнетов Г. Б. Общая педагогика : [ учеб. пос. ] / Г. Б. Корнетов; [2-е изд., перераб. и доп.]. - М. : Изд-во АСОУ, 2009. 296 с. 8. Мертенс Е. С. Развитие культурно-образовательной среды Смоленской губернии во второй половине XIX-начале XX века : дис. канд. пед. наук : 13.00.01 / Елена Сергеевна Мертенс. - Смоленск : Смоленский гос. ун-т, 2006. - 218 с. 9. Петренко Е. А. Формирование профессионального самосознания в культурно-образовательной среде вуза: автореф. дис. на соискание ученой степени канд. философ. наук : спец. 09.00.13 / Е. А. Петренко. - Ростов н/Д.: Южный федеральный ун-т, 2007. - 23 с. 10. Харламова М. И. Педагогические возможности культурно-образовательной среды провинциального города России в духовно-нравственном воспитании учащихся: дис. ... канд. пед. наук : 13.00.01 / Марина Александровна Харламова. Воронеж : Воронежский гос. пед. ун-т, 2010. - 175 с.

УДК 372(09)(73) «18/19»

T. А. Клюшнікова,

Ніжинський державний університет імені Миколи Гоголя

\title{
ВПЛИВ ІДЕЙ Ф. ФРЕБЕЛЯ НА РОЗВИТОК СУСПІЛЬНОГО ДОШКІЛЬНОГО ВИХОВАННЯ У СПОЛУЧЕНИХ ШТАТАХ АМЕРИКИ
}

Клюшнікова Т. А. Вплив ідей Ф. Фребеля на розвиток суспільного дошкільного виховання у Сполучених Штатах Америки.

Автор статті визначає особливості впливу педагогічних ідей Ф.Фребеля на розвиток суспільного дошкільного виховання у Сполучених Штатах Америки (кінець XIX - початок XX ст.) та аналізує працю С. Холла «Педагогіка дитячого саду».

Ключові слова: Ф. Фребель, педагогіка дитячого саду, фребелівські «дари», фребелівські заняття, С. Холл, Сполучені Штати Америки, суспільне дошкільне виховання, фребелівські курси.

Клюшникова Т. А. Влияние идей Ф. Фребеля на развитие общественного дошкольного воспитания в Соединненных Штатах Америки. 
Автор статьи определяет особенности влияния педагогических идей Ф. Фребеля на развитие общественного дошкольного воспитания в Соединенных Штатах Америки (конец XIX - начало XX ст. ) и анализирует работу С. Холла «Педагогика детского сада».

Ключевые слова: Ф. Фребель, педагогика детского сада, фребелевские «дары», фребелевские занятия, С. Холл, Соединенные Штаты Америки, общественное дошкольное воспитание, фребелиевские курсы.

Klyushnikova T. A. The influence of F. Froebel's ideas on the development of social childcare in the USA.

The author of the article definds influence of F. Froebel's ideas on the development of early childhood education in the USA and analyses work of S.Hall on pedagogy of kindergarten of the German educator.

Key words: pedagogy of kindergarten, Froubel gifts, Froubel classes, S.Hall, USA, public preschool education, Froubel courses.

На сучасному етапі реформування дошкільної освіти в Україні особливо доцільним $є$ вивчення історичного розвитку суспільного дошкільного виховання зарубіжних країн. В історико-педагогічній науці засновником закладу суспільного дошкільного виховання дитячого саду вважається видатний німецький педагог Ф. Фребель. Використання його ідей щодо організації дитячих садів, практики їх роботи та підготовки вихователів у кожній країні мало свої особливості.

Вивченням розвитку суспільного дошкільного виховання у США (кінця XIX - початку XX ст.) займалася відомий український педагог С. Русова. Сучасними дослідниками розвитку суспільного дошкільного виховання в зарубіжних країнах, зокрема в США, $\epsilon$ російські науковці Л. Парамонова, С. Протасова.

Вивчення історико-педагогічного досвіду розвитку суспільного дошкільного виховання зарубіжних країн та творче його засвоєння вітчизняними педагогами дозволяє якісно модернізувати роботу дошкільних навчальних закладів.

Метою статті є з'ясування впливу педагогічних ідей Ф. Фребеля на теорію і практику суспільного дошкільного виховання в США кінця XIX - початку XX ст.

Перший дитячий сад у США був організований у 1855 році у Віксонсіні учнями Ф. Фребеля, що емігрували з Німеччини після революції 1848 року. Вивчення проблеми дошкільної освіти в США було започатковане американським педагогом Генрі Бернардом (Barnard) у другій половині 50-х років XIX століття. Завдяки його публікаціям була привернута увага американських педагогів до питань виховання дітей дошкільного віку. Приватні особи почали відкривати дитячі сади. Але їх справа не мала успіху. Причиною вважали недосконалість і «фантастичність» фребелівської системи, яку часто критикували [2].

На твердий грунт фребелівський рух у США став з 1867 року, «коли Слизавета Пібоді, знавець педагогічної системи Ф. Фребеля і засновниця дитячого саду в місті Бостоні, заснувала Американський фребелівський союз» [1, с. 74]. Починаючи з 1870 року, крім приватних, почали з'являтися дитячі сади, засновані на кошти благочинних товариств i пожертв окремих приватних осіб. Вони вбачали в дитячому саду заклад для виховання дітей-сиріт і дітей робітничої бідноти. Перший благочинний дитячий сад в Америці був заснований у 1870 році в місті Флешинг штат Нью-Йорк.

Генрі Бернард у своїх доповідях союзному сенату (1868 р.) і палаті представників (1870 р.) з народної освіти в окрузі Колумбії вказував, що «...першою ланкою у міській шкільній системі повинна бути школа, у якій навчання велося б виключно у формі гри..., і перші кроки в розвитку дитини повинні проходити через дитячий сад» [2]. Показавши у своїх виступах безпосередній зв'язок дитячого саду зі школою, Генрі Бернард дав поштовх до включення дитячих садів у шкільну систему.

Перший дитячий сад, що увійшов до міської шкільної системи, був відкритий у Бостоні в 1870 році. У 1873 році у Сент-Луї з'явився перший міський дитячий сад, а також 
засновано перший дитячий сад для чорношкірих дітей і класи для підготовки чорношкірих вихователів.

Кількість дитячих садів у США дуже швидко зростала, що потребувало підготовки спеціалістів дошкільної освіти. Перша школа, що готувала педагогів для дитячих садів була відкрита в 1870 році в Бостоні на благочинні кошти Пауліни Шо (Pauline A. Shaw). Також на кошти цієї пані при школі була організована спеціальна бібліотека та в період 3 1877 по 1888 рік 31 дитячий сад у містах Бостон, Кембрідж, Бруклін. У США, крім Пауліни Шо, відомою своєю благочинною діяльністю у сфері розвитку суспільного дошкільного виховання була Слизавета Гарісон з міста Чикаго.

31880 року при вчительських інститутах почалося заснування спеціальних відділів 3 підготовки фребелічок на базі гімназійної освіти вступників. Перший такий відділ разом 3 дитячим садом був відкритий при Меннісотському вчительському інституті. Станом на 1903 рік при вчительських інститутах США було організовано роботу 54 відділів 3 підготовки фребелічок і 137 приватних фребелівських курсів. Термін навчання на фребелівських курсах становив два-три роки. Чикагський і Колумбійський університети ввели на своїх фребелівських відділеннях чотирирічні курси, після закінчення яких видавали відповідні дипломи. Перелік дисциплін, що викладалися в порівнянні з першими фребелівськими курсами, значно розширився. Але, як і в навчальному плані перших приватних фребелівських курсів, в університетах до навчального плану було включено вивчення фребелівської системи.

Аналіз розкладу занять американського дитячого саду та опису навчально-виховного процесу в ньому показує чітке наслідування фребелівської системи дитячого саду. Розклад включає вранішню молитву та привітання, маршировку, фізичні вправи та ритмічні рухи, заняття 3 «дарами», бесіди, інші фребелівські заняття: 1) з природними матеріалами піском, глиною, предметами 3 природи (нанизування насіння, ягід, мушель, фігурне розташування та наклеювання природного матеріалу, зібраного на прогулянках); 2) наклеювання геометричних фігур окремо і в поєднанні, створення інших геометричних форм; 3) вирізання із паперу вільне і за малюнком; 4) робота пензликом при розфарбовуванні різних форм, малювання ліній; 5) складання із паперу геометричних форм і форм життя; 6) роботи зі смужками паперу, з намистом; 7) екскурсії і прогулянки. Наслідуючи Фр. Фребеля у проведенні занять, американські фребелічки дотримувалися систематичності, послідовності в навантаженні дітей навчальним матеріалом, що дозволяло спиратися на досвід дітей при ознайомленні з новим матеріалом. Великого значення надавалося розвитку зовнішнього вияву ходу мислення дитини, що досягалося спонуканням дітей до пояснення своїх дій.

Поширення фребелівських ідей щодо організації роботи дитячого саду в США в порівнянні з іншими країнами мало свої особливості. Дитячі сади працювали в одну зміну 3 дев'ятої до дванадцятої години. Американські педагоги були переконані в тому, що для роботи вчительки-фребелічки та дітей ефективною буде перша зміна, оскільки в другій половині дня спостерігається психічне та фізичне виснаження. Час другої зміни вчителькою-фребелічкою дитячого саду США використовувався для відвідування дітей вдома, проведення батьківських нарад, які, як вважалося, мали великий вплив на «успіхи iii роботи», підготовки до занять, спілкування 3 колегами задля професійного росту, самоосвіти.

Стрімке збільшення кількості дитячих садів у США пояснюється довірою і підтримкою суспільства такого виду виховання дітей дошкільного віку, що є наслідком гарної підготовки спеціалістів цієї галузі. Також цьому «...сприяє доведена досвідом висока успішність дітей, що вступають після них (дитячих садів - Т. К.) до початкової школи, у порівнянні з тими дітьми, що не пройшли фребелівської школи» [2, с. 109].

Оцінку педагогічній системі Ф. Фребеля, а також практиці роботи дитячих садів за його системою, зроблено видатним американським психологом і педагогом Стенлі Холлом. Це один $з$ небагатьох науковців, який, даючи оцінку фребелівській педагогічній системі у 
своїй праці «Педагогіка дитячого саду», запевняє читачів, що він «...прочитав майже кожне його друковане слово, відвідав багато десятків дитячих садів у себе і за кордоном, прочитав в університеті цілий курс про його систему, видав збірник питань, що стосуються незрозумілих сторін, і отримав вичерпні відповіді від кращих представників цієї системи, завжди брав участь в одній або більше конференціях 3 питань про дитячі сади при літній школі Кларського університету і в одній при нашому «з'їзді у боротьбі за благо дітей», у липні 1909 зібрав і скрупульозно вивчив майже всю літературу з цієї проблеми» [3, с. 27-28]. С. Холл називає себе справжнім послідовником Ф. Фребеля, розуміючи його педагогіку як таку, що має внутрішні можливості для розвитку i вдосконалення на основі найсучасніших досягнень психологічної і педагогічної науки.

Американський дослідник у своїй праці «Педагогіка дитячого саду» визначив такі прогресивні ідеї Ф. Фребеля:

1. Німецький педагог сформулював біогенетичний закон, раніше ніж він був відкритий ембріологією. Цей закон прийнято генетичною психологією.

2. Ф. Фребель уважав, що інтелектуальний розвиток дитини залежить від розвитку «більш широкого життя почуття й емоцій», «інстинктів».

3. Німецький педагог був предтечею початку психологічного вивчення дитини. Він застосував метод самодіяльності в навчанні та вихованні дітей дошкільного віку, використовуючи гру, у якій дитина могла виявляти й розвивати свої творчі здібності; указав на те, що, спостерігаючи за грою дітей, ми можемо виявити їх вроджені здібності.

4. Ф. Фребель перший застосував у вихованні пантеїстичні поняття «...про те, що ми живемо, рухаємося й існуємо в Богові». С. Холл вважає, що ця віра Ф. Фребеля «...принесла з собою нові погляди, нові методи» у виховання.

5. Німецький педагог вірив у хорошу природу дитини, на противагу кальвіністичним ідеям про ii зіпсованість 3 народження; такі його погляди на природу дитини заперечували грубе втручання в ііі розвиток.

6. Ф. Фребель вважав самоцінним кожен етап розвитку людини, що є фундаментом для повноцінного розвитку в наступному етапі.

7. Завжди буде сучасною думка німецького педагога про те, що ми повинні жити для дітей і разом з ними, що «єдиним мірилом довершеності держави, сім'ї, церкви, школи, цивілізації $є$ те, до якої повноти зрілості вони доведуть дітей і молодь» [3].

8. Порівнюючи дитину з зерном, що лежить у землі і не бачить сонця, не відчуває безпосередньо дощу, але все ж відчуває будь-яку переміну в температурі, вологості або світлі, німецький педагог випередив своїх сучасників, надаючи великого значення безсвідомому у вихованні.

9. Ф. Фребель був родоначальником навчання дітей дошкільного віку основам гігієни в умовах дитячого саду. Він вважав здоров'я основою і мірилом всього, тому закликав піклуватися про нього з дитячих років.

С. Холл називає помилки, яких допустився Ф. Фребель в теорії і практиці дитячого саду:

1. Ф. Фребель не вмів ясно виразити свої думки. Часто повторювався і говорив, що найпростіші речі і вчинки не можуть бути передані словами; на думку американського науковця, праці Ф.Фребеля потребують перевидання «...із значною очисткою від повторень і детальним поясненням його темностей» [3, с. 36].

2. С. Холл вказує на непрактичність педагогіки Ф. Фребеля, що полягає у використанні для навчання предметів неживої природи. На його думку, це пов'язано 3 архітектурною освітою німецького педагога, його заняттями кристалами, а також із тим, що біологія як наука ще тільки зароджувалася.

3. Американський науковець відзначає, що більшість послідовників Ф. Фребеля були жінки «...бездітні, але вже в тому віці, коли дається взнаки пустота, яку може заповнити тільки сімейне життя» [3]. С. Холл порівнює захоплення жінок Ф. Фребелем із 
поклонінням бездітних монахів Діві Марії, у яких «розумова діяльність розвинулася в схоластику» [3, с. 37].

Наслідування Ф. Фребеля його послідовниками, американський педагог називає «дрібним містицизмом». С. Холл уважав, що для правильного розуміння і подальшого розвитку фребелівської педагогіки вихователькам, керівникам дитячих садів не вистачало університетської освіти. Серед прибічників Ф. Фребеля американський педагог лише двохтрьох уважає освіченими, але такими, що «нічого не розуміють у сучасній психології» [3, c. 38].

С. Холл визначив основні помилки, яких припустилися послідовники Ф. Фребеля, упроваджуючи його ідеї в практику роботи дитячих садів у США:

1. Застосування в навчально-виховному процесі «ігор матері». Ці ігри американський педагог називає «невдалим доробком педагогіки Ф.Фребеля», що не є тим цінним матеріалом, який слід було б наслідувати.

2. Надання переваги в педагогічному процесі дитячих садів заняттям 3 «дарами» $\mathrm{i}$ заняттям загалом. С. Холл уважав помилковим твердження Ф. Фребеля, що «дари» $\epsilon$ прекрасною «граматикою гри» й «азбукою промисловості». Гра і ручна праця в той час були мало розвинуті. Гра 3 «дарами», на думку американського науковця, корисна для сільських дітей і не відіграє ніякої ролі в роботі з міськими дітьми. У дитячому саду значна увага приділяється малюванню правильних геометричних форм, що не відповідає дитячій техніці виконання та не є засобом розвитку художнього смаку, переконує С. Холл. Захоплення дітей діяльністю і прагнення досягти результату на заняттях в дитячому саду може призвести до їх перевтоми. Велике навантаження на фребелівських заняттях припадає на дрібні мускули, які в дітей дошкільного віку ще не готові до такої роботи.

3. Недотримання санітарно-гігієнічних норм. На думку С. Холла, цим дитячі сади порушують заповіді Ф. Фребеля. Німецький педагог мріяв про те, щоб «дитина жила поза приміщенням», кожній він би «дав грядку квітів, щоб вона мала доступ до матері-землі», він підкреслював «необхідність у достатній кількості здорової діяльності для всього тіла» i «розумів гігієнічну користь дозвілля» [3, с. 48].

Американський педагог наголошує, що Ф. Фребель залишив свою працю незакінченою, а те, що він зробив, потребує пояснення і розвитку, щоб «його дух не був задушений буквою» [3]. Виходячи з цього, С. Холл говорить, що для створення ідеального дитячого саду потрібно провести певні реформи. Він пропонує створити комітет з десяти осіб, які добре знають справу дитячого саду. Науковець переконує, що для проведення глибоких реформ потрібно було б провести дослідження в галузі дошкільної педагогіки та психології протягом кількох років, але вже на основі даних сучасної науки можна здійснити покращення в роботі дитячих садів.

С. Холл зауважує, що, приділяючи багато уваги навчанню дітей, їх розумовому розвитку, фребелівські дитячі сади забувають про фізичний догляд, якого дуже потребують маленькі діти. Тому слід більше уваги звертати на догляд і зміцнення тіла, і «...менші вимоги ставити до руки й ока». Задля цього потрібно широко використовувати в роботі з дітьми танець, який виховує відчуття ритму і в цьому можна значно перевершити вимоги Фребеля» [3].

Американський педагог теоретично визначив шляхи вдосконалення ігрової педагогіки Ф. Фребеля:

1. Потрібно розширити перелік іграшок, особливу увагу звернути на «ляльку з іiі величезною виховною силою» [3].

2. Кубики Ф. Фребеля потрібно зробити більшими за розмірами, щоб їх було зручно дитині тримати в руках. Окрім кубиків, як іграшки С. Холл рекомендує використовувати залишковий матеріал.

3. При ідеальному дитячому саду обов'язково повинен бути майданчик для ігор, на території якого розміщено матеріал для будування: каміння різне за формою, якістю і такої величини і маси, щоб діти могли його перекочувати 3 місця на місце; дошки $\mathrm{i}$ 
колодки, із яких діти могли б без цвяхів споруджувати будівлі достатньо великого розміру, щоб у них увійти, залізти.

4. Як будівельний матеріал С. Холл рекомендує широко використовувати сніг, звертаючи увагу педагогів на позитивну дію зимового повітря на організм дитини.

5. Науковець закликає педагогів до створення умов для більш тісного і тривалого контакту дітей з живою природою - тваринами і рослинами.

Особливу увагу вихователів дитячих садів дослідник звертає на навчання дітей мови, головне завдання якого полягає не тільки в навчанні вільному спілкуванню, а й розширенні словника дитини. Задля цього С. Холл радить проводити 3 дітьми бесіди (індивідуальні та групові), розповідати їм історії та міфи, казки, деякі уривки з Старого Заповіту. Розповіді потрібно пов'язувати з іграми та драматизацією. Дослідник зазначає: «Розповідання казок повинно було б стати професією, а якщо б мені довелося обирати вчительок для дитячого саду, то я вважав би іспит у цьому відношенні найголовнішим, тому що саме таким чином передавалася культура задовго до появи книг» [3, с. 53-54]. На думку науковця, дошкільний вік найбільш сприятливий для початку вивчення іноземних мов. Тому він рекомендує розпочинати вивчення іноземної мови у старшій групі для тих дітей, яким вона буде потрібна в подальшому житті.

С. Холл уважає, що дитячий сад - це найкращий осередок вивчення процесу розвитку дитини, у якому не місце «культу заплутаного символізму». Ф. Фребель і його педагогіка повинні очолювати «...цей рух уперед, а не плентатися за колесами його колісниці» [3, c. 63]. Науковець зазначає, що до цих пір зовсім мало зроблено спостережень за дітьми від народження до трьох років, а дитина від двох 3 половиною до п'яти-шести років майже невідома науці. Для виправлення ситуації С. Холл пропонує залучити до роботи в дитячому саду велику кількість жінок з вищою психолого-педагогічною освітою, які могли б вести «книгу життя і здоров'я» кожної дитини, котра відвідує дитячий сад. С. Холл звертає увагу на дитячий сад «...своїх колег за професією, що шукають галузь для застосування філософії», і вважає, що «кожен вихователь і навіть університетський професор багато виграє від детального вивчення дитячого саду» [3, с. 63-64]. Він рекомендує цілеспрямовано готувати фахівців для систематизації вже відомих знань про дітей дошкільного віку, здатних керувати новими дослідженнями в цій галузі.

Порівнюючи європейські й американські дитячі сади, С. Холл відзначає, що перші мають кращі умови для задоволення потреб дітей. Педагогічний процес дитячих садів країн Західної Європи передбачає часте спілкування дітей з живою природою, проведення багато часу на свіжому повітрі. Прогулянки зазначені в розкладі, у деяких дитячих садах розроблено програми прогулянок із вказівками до спостережень. Якщо є можливість, діти відвідують ботанічні та зоологічні сади. Поряд з фребелівськими «дарами» в дитячих садах Європи багато інших іграшок: ляльок, мотузочок для стрибання, лопаток, відерець, формочок для піску і глини, настінних картин, книжок з картинками, у деяких дитячих садах діти самі виготовляють іграшки. Біля кожного дитячого саду є майданчик для ігор, обсаджений деревами, критий простір для ігор під час дощу, сад. У будівлі дитячого саду передбачено кімнати для ігор [3, с. 79].

Познайомившись 3 роботою консервативних дитячих садів країн Європи та США, С. Холл прийшов до висновку, що виховательки не враховують у своїй роботі вікових особливостей дітей та не бачать зв'язку між попередніми та наступними періодами розвитку дитини. У слухачок шкіл для садівниць низький рівень психолого-педагогічної підготовки. Зміст всієї американської літератури про дитячий сад дозволяє сумніватися в тому, що іï автори знайомі з педагогікою Ф. Фребеля, «...Фребелем, якого вони, мені здається (С. Холлу - Т.К.), передають перерахуванням дев'яти пунктів, але якому вони постійно заперечують основним напрямком своїх творів» [3, с. 84].

С. Холл відзначає відсутність належної кількості перекладів англійською мовою творів Ф. Фребеля, тому вони не стали відомі широкому колу читачів. Пошуки хоча б одного 3 керівників справи дитячого саду, який би прочитав повністю праці Ф. Фребеля, привели 
С. Холла до такого висновку: «Вони, звичайно, проглянули деякі із його відомих книжок, що ілюструють їх власні погляди. Але Фребель ... наповнений незв'язними, якщо не протилежними поглядами, тому послідовники ніколи не дійдуть згоди. Якщо я правильно розумію ідеї Фребеля, то, на мою думку, його огорнув би жах від того, що він би побачив у середньому американському дитячому саду, і надав би перевагу хорошому денному притулку» [3, с. 85].

Отже, аналіз історико-педагогічних джерел засвідчує значний вплив ідей Ф. Фребеля на розвиток суспільного дошкільного виховання США. Американські педагоги та особи, що опікувалися організацією дитячих садів, у своїй справі орієнтувалися на концепцію дитячого саду німецького педагога. Грунтовну оцінку педагогіки дитячого саду Ф. Фребеля зроблено американським педагогом С. Холлом. Основними недоліками дидактики дитячого саду науковець вважав спробу німецького педагога зробити заміну безпосереднього спостереження середовища, що оточує дитину, на містично-символічну систему «дарів»; використання ігор як засобу навчання в нав'язливій формі із наслідками перевтоми вихованців. С. Холл був противником сліпого копіювання фребелівської педагогіки дитячого саду. Американський педагог ініціював продовження справи Фр. Фребеля за умови врахування педагогами досягнень психологічної науки.

\section{Література}

1. Блонский П. П. Введение в дошкольное воспитание: [лекции, организованные Кружком совместного воспитания и образования детей и читанные в Московском Университете имени А. Л. Шанявского] / П. П. Блонский - М., 1915. - 139 с. 2. Егоров Н. Дошкольное и внешкольное образование в иностранных государствах / Н. Егоров. - Петроград : Сенатская типография, 1917. 262 с. (Извлечено из Журнала Министерства народного просвещения за 1916-1917 годы). 3. Холл С. Педагогия детского сада [под редакцией и предисловием А. У. Зеленко] / Стенли Холл. - М .: Госиздат, 1920. - 95 с.

УДК 37.014.5

С. С. Лупаренко,

кандидат пед. наук, доцент, Харківський національний педагогічний університет імені Г. С. Сковороди

\section{РОЗВИТОК СИСТЕМИ ОХОРОНИ МАТЕРИНСТВА Й ДИТИНСТВА В УКРАЇНІ В 1920-40-х pp.}

Лупаренко С. Є. Розвиток системи охорони материнства й дитинства в Україні в 1920-40-х рр.

Стаття присвячена дослідженню особливостей розвитку системи Охматдит в Україні протягом 1920-40-х pp., а саме: започаткування державної дитячої оздоровчої діяльності, задля чого розвивалась мережа дитячих оздоровчих закладів; визначення кола актуальних питань (організація харчування дітей, боротьба з безпритульністю), які мали розв'язуватися на державному рівні.

Ключові слова: охорона материнства й дитинства, дитина, оздоровча діяльність, безпритульність, дитячі оздоровчі заклади.

Лупаренко С. Е. Развитие системы охраны материнства и детства в Украине в 1920-40-х гг.

Статья посвящена исследованию особенностей развития системы Охматдет в Украине на протяжении 1920-40-х гг., а именно: зарождение государственной детской оздоровительной деятельности, что предусматривало развитие сети детских оздоровительных учреждений; определение круга вопросов (организация питания детей, борьба с беспризорностью), которые должны были решаться на государственном уровне.

Ключевые слова: охрана материнства и детства, ребенок, оздоровительная деятельность, беспризорность, детские оздоровительные учреждения. $40^{\text {th }}$.

Luparenko S. E. The development of the system of maternal and child health in Ukraine in the 1920- 